[Pericardioscopy in differential and treatment of pericardial effusion]. Modern Technologies in Medicine, 2011, 62-65.

[15] Nikonenko, A. S., Zavgorodniy, S. N., Gubka, A. V., Golovko, N. G., Klimenko, A. V., Osaulenko, V. V. et. al. (2011). Hirurgicheskoe lechenie bolnyih ostryim ekssudativnyim perikarditom i ugrozoy razvitiya tamponadyi serdtsa s primeneniem miniinvazivnyih tehnologiy [Surgical treatment of patients with acute exudative pericarditis and threat of development of cardiac tamponade with the use of minimally invasive technologies]. Modern medical technologies, 3-4, 449-450.

[16] Seterovic, P. M., Ristic, A. D., Maksimovic, R., Tatic, V., Ostojic, M., Kanjuh, V. (2003). Diagnostic Value of Pericardial Biopsy: Improvement With Extensive Sampling Enabled by Pericardioscopy. Circulation, 107 (7), 978-983. doi: http://doi.org/10.1161/01.cir.0000051366.97361.ea

[17] Adler, Y., Charron, P., Imazio, M., Badano, L., Barón-Esquivias, G., Bogaert, J. et. al. (2015). 2015 ESC Guidelines for the diagnosis and management of pericardial diseases. European Heart Journal, 36 (42), 2921-2964. doi: http://doi.org/10.1093/eurheartj/ehv318

[18] Maisch, B., Rupp, H., Ristic, A., Pankuweit, S. (2013). Pericardioscopy and epi- and pericardial biopsy - a new window to the heart improving etiological diagnoses and permitting targeted intrapericardial therapy. Heart Failure Reviews, 18 (3), 317-328. doi: http://doi.org/10.1007/s10741-013-9382-y

[19] Maisch, B., Rupp, H., Ristic, A., Pankuweit, S. (2013). Pericardioscopy and epi- and pericardial biopsy - a new window to the heart improving etiological diagnoses and permitting targeted intrapericardial therapy. Heart Failure Reviews, 18 (3), 317-328. doi: http://doi.org/10.1007/s10741-013-9382-y

[20] Khandaker, M. H., Espinosa, R. E., Nishimura, R. A., Sinak, L. J., Hayes, S. N., Melduni, R. M., Oh, J. K. (2010). Pericardial Disease: Diagnosis and Management. Mayo Clinic Proceedings, 85 (6), 572-593. doi: http://doi.org/10.4065/mcp.2010.0046

\title{
INDICATORS OF RESPIRATORY SYSTEM IN CONDITIONS OF CHRONIC ACTION OF HARMFUL ENVIRONMENTAL FACTORS WITH TYPE OF BODY CONSTITUTION
}

\author{
Volodymyr Pshybelsky \\ Department of Human Health and Physical Rehabilitation \\ Private Higher Educational Institution "Academy of Recreational Technologies and Law" \\ $9 b$ Kivertsivska str., Lutsk, Ukraine, 43000 \\ ukr_vol1@ukr.net \\ Oleksandr Zhuravlov \\ Department of Human and Animal Physiology \\ Lesya Ukrainka Eastern European National University \\ 9 Potapova str., Lutsk, Ukraine, 43025 \\ zhuravlov.oleksandr@eenu.enu.ua \\ Tetiana Shevchuk \\ Department of Human and Animal Physiology \\ Lesya Ukrainka Eastern European National University \\ 9 Potapova str., Lutsk, Ukraine, 43025 \\ tetyana_shevchuk_2013@ukr.net \\ Olena Zhuravlova \\ Department of General and Social Phychology and Sociology \\ Lesya Ukrainka Eastern European National University \\ 9 Potapova str., Lutsk, Ukraine, 43025 \\ aln.frolova@gmail.com
}




\begin{abstract}
The article presents the results of the study of the peculiarities of the respiratory system functioning in unfavorable environmental conditions in workers involved in industrial production and agrarian sector, taking into account the type of constitution of their bodies. Investigation of the influence of the complex of anthropogenic factors associated with production on the parameters of the respiratory system revealed a significant level of interconnection of the investigated parameters with anthropometric indicators.

During the experiment, a significant decrease in the functional lung capacity in the studied subjects involved in industrial production was shown, compared with the control group and workers of argo-industrial production. Such a trend may be evidence of functional violations of tracheobronchial conduction, which is indirectly confirmed by the values of the Tifno index, which is the main method of an objective assessment of respiratory tract imperfections, and which is characterized by significantly lower values in the group of workers involved in industrial production compared with residents relative to environmentally friendly areas.

The analysis of the pneumatachographic survey performed on the basis of the Pignier index revealed some differences in the functional parameters of the respiratory system in the groups of hyposthenics (capacity of the lungs) and hypersthenics (maximum volume velocity of $75 \%$ ). In the group of normosthenics, intergroup differences were found for the values of functional lung capacity in comparison with all groups, and for the Tifno index, the reliable difference between the indicators was noted only between the group of industrial workers and the control group.
\end{abstract}

Keywords: pneumotachography, production conditions, industrial production, agro-industrial production, respiratory system.

\title{
1. Introduction
}

The study of adaptive-compensatory landslides in the organism, caused by the influence of environmental factors, acquires a qualitatively new scale and transforms into one of the fundamental medical-biological problems. Over the past ten years there has been a steady increase in the frequency and severity of respiratory diseases [1,2]. According to many scientists, the assessment of the impact of adverse factors on the human body associated with environmental pollution, is the most important task of biological science at the present stage [3].

At the present stage, the influence of environmental factors on the development of respiratory diseases in the population of urbanized areas is generally recognized, while factors of the production environment and their effects on the organism are rarely analyzed taking into account the peculiarities of the body structure of workers. The main manufacturing factors affecting the airways: agricultural and industrial dust with particle sizes from $0.25 \mathrm{~nm}$ to $30 \mathrm{~nm}$, steam and heavy metals, adverse weather conditions (excessive dryness or humidity, sharp temperature fluctuations, drafts, etc.). Harmful effects on the body carry out general toxic, sensitizing, carcinogenic, mutagenic effects, and the increase in the effect of the influence, scientists associated with the common complex impact of allergens and chemical pollutants of the environment. It is proved that the intensive environmental load negatively affects the metabolic resistance of the organism, suppresses the system of local protection [4, 5], especially with prolonged action [6]. These changes lead a certain part of the population to stable respiratory hyperresponsiveness, obstruction of small bronchi, morphological rearrangement of the mucous membrane of the airways and, in the future, the formation of acute and chronic inflammation [4, 7], as well as the development of a number of nonspecific pathological processes among which the leading place oxidative stress [10]. In addition, the analysis of modern literature suggests that industrial toxic substances affect not only people engaged in production $[11,12]$, but also on the population of so-called rural areas by pollution of the environment [13].

\section{Aim of research}

Determination of the peculiarities of physiological changes in the respiratory system of the workers of the agrarian sector and industrial production, depending on the type of their body structure.

\section{Methods of research}

Investigation of the indicants of external respiration was carried out on the basis of the Laboratory of environmental physiology at the East European National University named after Lesya 
Ukrainka in the 90-hour period of 21-35 years (average age 26.40 \pm 3.66 ) during the spring-autumn 2016-2017 years. The study of complex spectrum was included in our research and included measurements of anthropometric indices, on the basis of which the Piene index is calculated and definition of the state of indicators of external respiration. Registration of indicators of the respiratory system was carried out with the help of pneumotachography technique on the complex of hardware and prognostic methods of inspection «Askold» (Kyiv, 1997). Referred to the purpose of the study all of the investigated patients were divided into 3 groups:

1) the control group (30 people) - inhabitants that resides in a relatively «pure» ecological zone (the population of the Kivertsi district);

2) agrarian sector (30 people) - inhabitants of agrarian districts, who work in the agricultural sector and consistently in contact with fertilizers and chemical products (the settlements who live in Ivanichivsky and Lokachinsky district);

3 ) industry (30 people) - inhabitants who work at the industrial enterprises of the chemical industry at least 10 years in the Lutsk.

Based on the results of measurements of height, body weight and chest circumference, physical indices were calculated [14].

The Pignet index (PI) characterizes the proportionality of the development and composition of the body structure. Applicable only to those who do not have signs of obesity. Formula for calculating the Pignet index $(\mathrm{PI})$ : $\mathrm{PI}=\mathrm{L}-(\mathrm{M}+\mathrm{O})$, where $\mathrm{L}-$ height in centimeters, $\mathrm{M}$ - mass in kilograms, $\mathrm{O}$ - chest girth in centimeters.

In our researches for the establishment of the type of constitution, the subjects examined the classification by V. M. Chernorutsky (1927): hyposthenic (asthenic type of body structure, the value of the Pignet index $>30$ c. u.), normosthenic (athletic type of body structure, the value of the Pignet index from 10 to 30 c. u.), hypersthenic (picnic type of the body structure, the value of the Pignet index $<10$ c. u.). [15].

Pneumotachography was used to record the rapid movement of the light during the periodic breathing and the removal of certain respiratory maneuvers. The method is oriented on the diagnostics of the type and degree of ventilation of the lungs at the base of the analysis of quantitative and qualitative changes of pneumotachographic pathways [16]. The study took place in the first half of the day, irrespective of meal.

The obtained data was processed by the method of variation statistics with the use of parametric and nonparametric criteria for the comparison of averages. To compare the studied groups, depending on the type of distribution of the values, the criterion of reliability of the Student ( $t$ ) was used for the comparison of the mean values and the Mann-Whitney (W) with the median and the degree of validity ( $\mathrm{p}$. The difference was reliable at $\mathrm{W}>2.1 ; \mathrm{t}>2.1 ; \mathrm{p}<0.05$. Correlation analysis of data was carried out using the Pearson correlation coefficient (r). Under the statistic analysis of the obtained results, the standart software packages and Statistica 6.0 were used.

\section{Results of research}

The analysis of the obtained data showed that the indicators of life capacity of the lungs of people working in agricultural production are significantly higher (5.24 \pm 1.53 liters) for those in the group involved in industry (4.58 \pm 1.24 liters) and inhabitants relatively environmentally friendly regions $(4,37 \pm 1,431)$, but do not show statistically significant differences in values. However, all values are within the age range.

The value of the indicator of functional lung capacity, which is used to diagnose tracheobronchial conduction disorders, unlike the previous one, is characterized by statistically significantly lower values in the group of people involved in the industrial sector than in the other two groups (Fig. 1).

The Tifno index, which is the main method for an objective assessment of airway patency violations, is characterized by a statistically significant decrease in the values of persons involved in industrial production compared with the control group (Fig. 2). Such a decrease in the index from industrial production may indicate the initial obstructive changes in the bronchial tree, while the indicators of the workers of the agro-industrial complex and the control group are within the age limit. 
It is worth noting that the Tifno index in the control group of the subjects showed a high correlation with the growth indices $(\mathrm{r}=-0.46)$, chest circumference $(\mathrm{r}=-0.30)$, age $(\mathrm{r}=-0.43)$, and the nature of interdependence is inversely proportional.

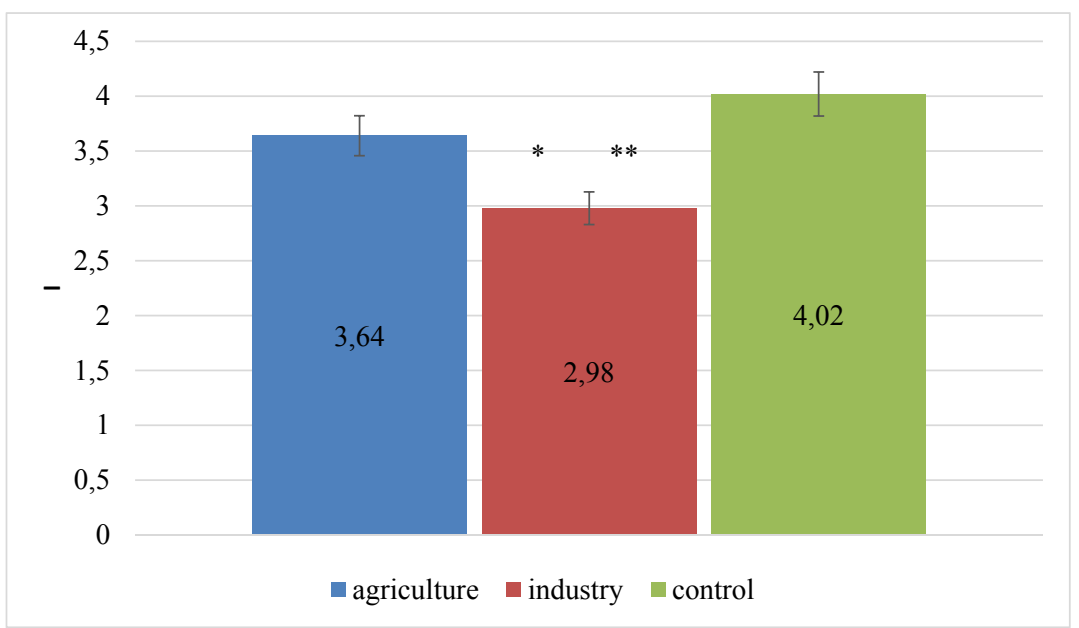

Fig. 1. Indicators of functional life capacity of lungs in the subjects undergoing chronic effects of various environmental factors: * - statistically significant difference of the indicators compared with the control group; $* *$ - statistically significant difference between the indicators among groups of people engaged in agricultural production and industry

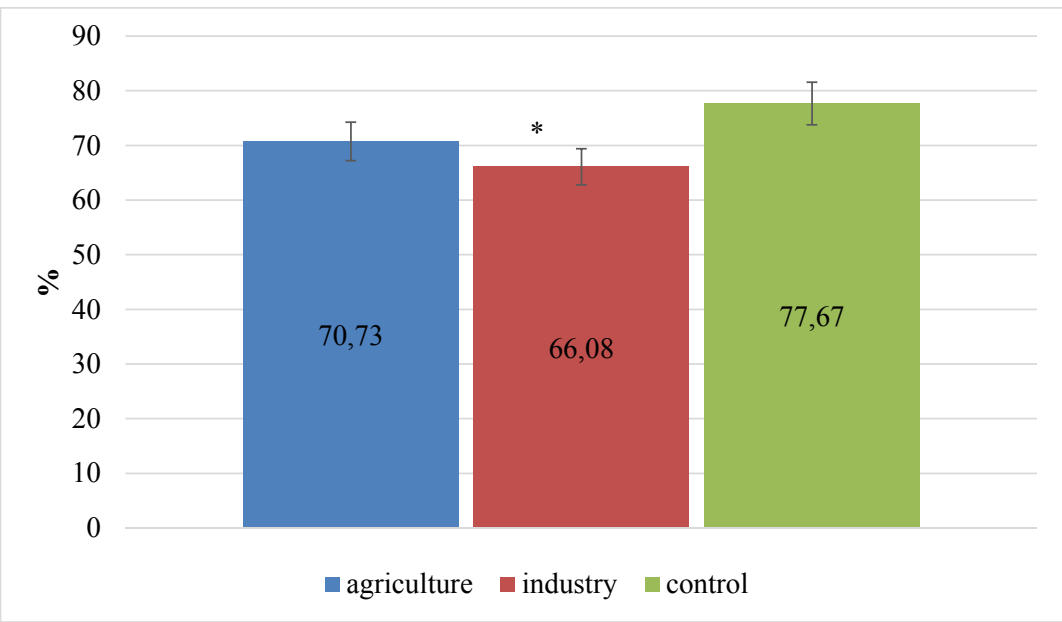

Fig. 2. Indicators of the Tifno index in the subjects undergoing chronic effects of various environmental factors: * - statistically significant difference of the indicators compared with the control group

Indicators of maximum volumetric rate of $25 \%, 50 \%$ and $75 \%$ of forced exhalation, which indicate, respectively, the patency of large and small bronchuses in all subjects did not reveal significant intergroup differences, except for the indicator MOS 50, which was significantly higher in the group of persons involved in the agricultural industry, in comparison with the control group (Fig. 3).

Correlation analysis of functional parameters of the respiratory system of the subjects showed a high level of dependence between the anthropometric data and the indicators MOS25 and MOS50. So the relationship between the MOS25 score and the height $(\mathrm{r}=0.48)$, weight $(\mathrm{r}=0.49)$, chest circumference $(r=0.33)$, age $(r=0.42)$ is directly proportional, whereas in the subjects undergoing chronic negative the influence of the factors of the production environment, this dependence is practically absent. Thus, the group of workers in the agro-industrial complex maintains a mod- 
erate correlation between the indicator MOS25 and growth $(\mathrm{r}=0.33)$, and in the group of industrial production, it completely disappears. This tendency can be evidence of the effect of more intense environmental influences on the respiratory system than the genetically determined dependence.

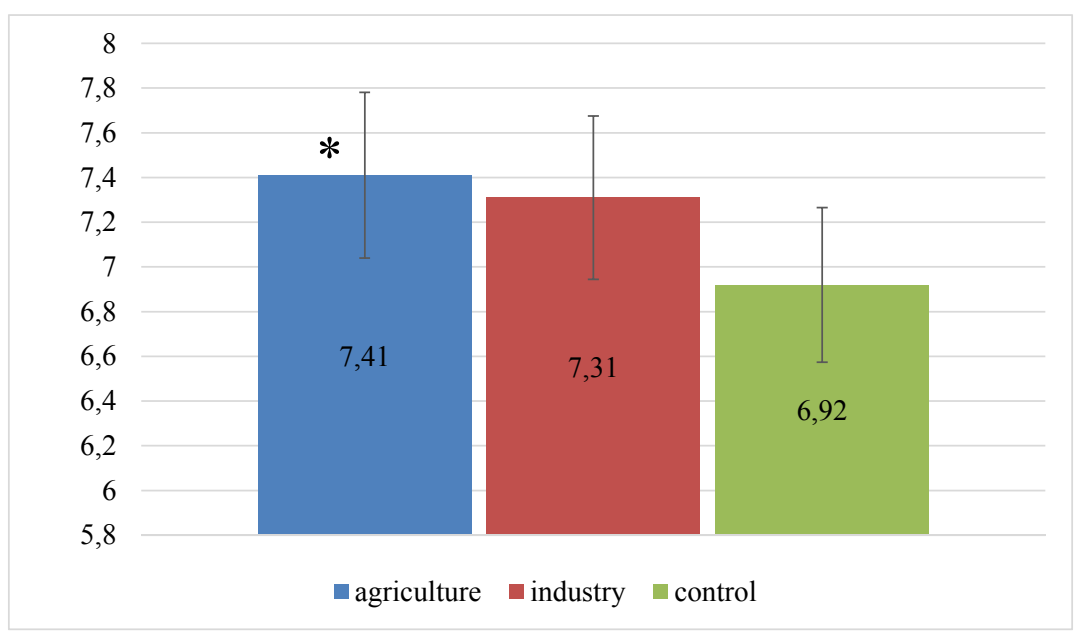

Fig. 3. The indicators of maximum volume velocity at the level of $50 \%$ of forced volume vital capacity in the subjects undergoing chronic effects of various environmental factors:

* - statistically significant difference of the indicators compared with the control group

At the next stage of the study, we analyzed the parameters of the respiratory system in workers of various industries, exposed to long-term influence of negative factors depending on the characteristics of physical development of man. The distribution of the studied subjects according to the values of the Pignet index in the study groups, selected according to the ratio of harmful environmental factors of the production environment, showed that all surveyed predominates the normosthenic type of body structure: in the group of workers in agriculture $-71 \%$, in industrial production $-48 \%$, and in the control group residents of environmentally friendly areas $-50 \%$.

It is interesting to note that individuals involved in agro-industrial enterprises do not have a hypersthenical type of body structure, whereas in the industrial workers and in the control group their percentage is $26 \%$ and $30 \%$, respectively.

The significance of forced volume vital capacity in a group of persons with a hyposthenic type of body constitution does not reveal a significant difference between the investigated people who work in industry or agriculture and residents of relatively clean areas (Fig. 4).

In the subjects with normosthenic type of constitution the presence of reliable $(p<0.05)$ differences of the forced vital capacity as between the comparison groups, distinguished by the peculiarities of harmful factors of the environment (workers of the agricultural and industrial complex) and their comparison with the control group of the subjects (rice 4). At the same time, residents of relatively environmentally friendly areas are characterized by higher values of the indicator.

In the group of hypersthenics, the absolute values of the indicator show a decrease in the industry, but the difference does not reach the level of statistically significant (Fig. 4).

Taking into account the previous indicator and previously described features, it is interesting to note the characteristics of the indicator of the volume vital capacity, taking into account the index of physical development. Thus, in the group of hyposthenic body building, statistically significant $(\mathrm{p}<0.05)$ is higher than the value of the indicator in the groups of agricultural workers, compared to the control group ( $4.72 \pm 0.811$ against $3.85 \pm 0.62$ liters).

In the subjects with normal and hypersthenic type of constitution, there were no significant differences in the values of volume vital capacity.

The Tifno index in the subjects undergoing chronic effects of harmful ecological factors in the production is characterized by lower rates in all groups, compared to the control group (Fig. 5). The level of reliably reaching differences in the hyposthenic group between the workers 
of the agroindustrial complex and control, among normosthenics - between persons involved in industrial production and control, as well as subjects with a hypersthenic type body constitution.

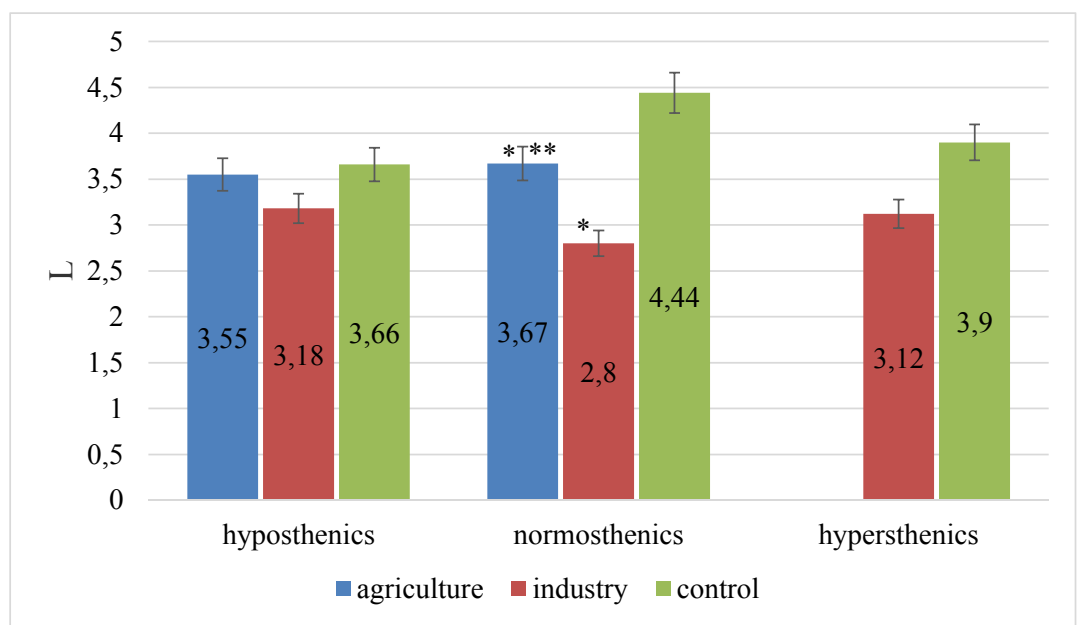

Fig. 4. Indicators of forced vital capacity of the lungs in the subjects undergoing chronic effects of various environmental factors depending on the type of constitution: * - statistically significant difference of the indicators compared with the control group; ** - statistically significant difference between the indicators among groups of people engaged in agricultural production and industry

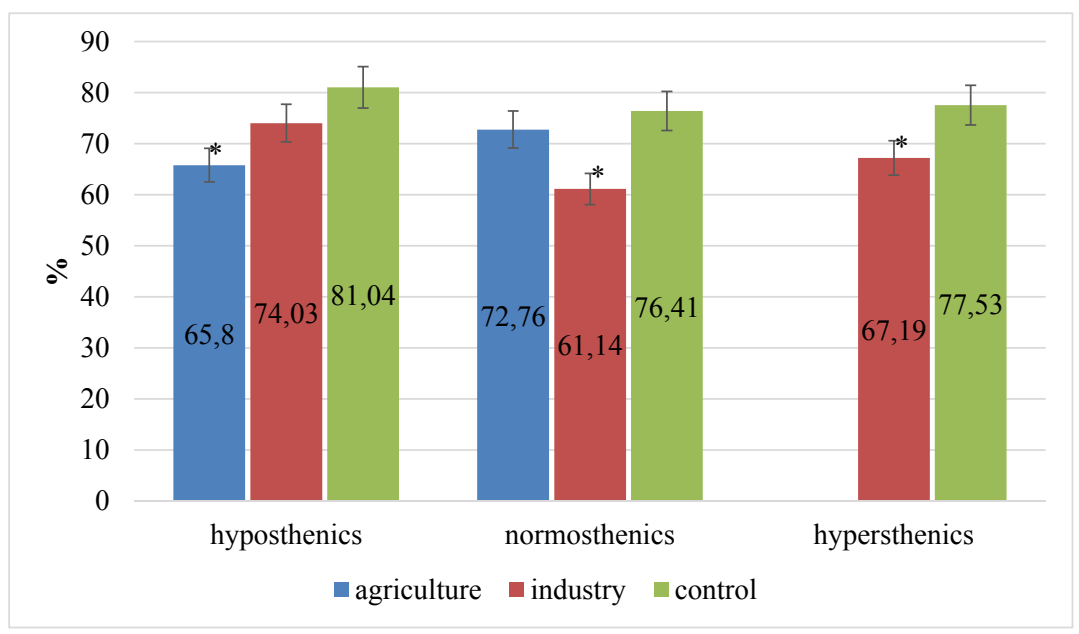

Fig. 5. Indicators of the Tifno index in the subjects undergoing chronic effects of various environmental factors depending on the type of constitution: * - statistically significant difference of the indicators compared with the control group

Indicators of maximum volumetric rate of $25 \%, 50 \%$ and $75 \%$ of volume vital capacity in subjects who were exposed to harmful production factors, do not statistically significantly differ between comparison groups, except for subjects with hypersthenic type body constitution. They showed statistically significant $(\mathrm{p}<0.05)$ higher values of MOSH75 in the subjects involved in the industry (6.05 \pm 0.86$)$, compared with the control group (3.59 \pm 1.07$)$.

\section{Discussion}

Investigation of the influence of the complex of anthropogenic factors associated with production on the parameters of the respiratory system revealed a significant level of interconnection of the investigated parameters with anthropometric indicators. At the same time, as already indicated above, the closest relationship between these indicators is noted in the group of persons 
living in a relatively environmentally clean area $[17,18]$. The lowest level of statistically significant correlations was found in the group of workers in the agro-industrial complex.

Concerning the intergroup features of the respiratory system, here the attention is paid to the significant decline in the indicators of functional lung capacity in the subjects involved in industrial production, compared with the other two groups of comparison [18, 19]. Such a trend may be evidence of functional violations of tracheobronchial conduction, which is indirectly confirmed by the values of the Tifno index, which is the main method of an objective assessment of respiratory tract imperfections, and which is characterized by significantly lower values in the group of workers involved in industrial production compared with residents relative to ecologically clean areas [20].

The validity of the division of the subjects studied into groups, taking into account the index of their constitution (Pignet index), was manifested in the fact that most of the studied parameters were characterized by a significant number of statistically significant correlation relations with this indicator. Such a feature of the obtained results made it possible to analyze the parameters of the respiratory system of persons who have been exposed to harmful factors in production for a long time, taking into account the groups allocated on graduations, which are based on the value of the Pignet index.

The analysis of the pneumotachographic survey performed on the basis of the Pignet index revealed some differences in the functional parameters of the respiratory system in the groups of hyposthenics (capacity of the lungs) and hypersthenics (maximum volume velocity of $75 \%$ ). In the group of normosthenics, intergroup differences are detected for the values of functional lung capacity when comparing all groups and the Tifno index when comparing workers of industrial enterprises and control groups.

\section{Conclusions}

1. The Pignet index made it possible to identify the predominance of normosthenic body type in all subjects (values ranged from $48 \%$ in the group of people involved in industrial production, up to $71 \%$ - in agricultural enterprises).

2. The value of functional lung capacity in the study subjects involved in industrial production is reduced in comparison with the workers of agricultural enterprises and with the control group, which may be evidence of functional disorders of tracheobronchial conduction, which is indirectly confirmed by the values of the Tifno index.

3. Analysis of the data of the pneumotachographic survey, based on the Pignet index, revealed some differences in the functional parameters of the respiratory system in the groups of hyposthenics (life capacity of the lungs) and hypersthenics (maximum volume velocity of $75 \%$ ). In the group of normosthenics, intergroup differences are detected for the values of functional lung capacity when comparing all groups and the Tifno index when comparing workers of industrial enterprises and control groups.

\section{References}

[1] Betts, K. S. (2011). Ambient Air Pollution and Infant Health: Home Monitors Make Cardiorespiratory Connections. Environmental Health Perspectives, 119 (9), 398. doi: http://doi.org/10.1289/ehp.119a398a

[2] Scherbakova, M. A. (2013). Ocenka vliyaniya zagryazneniya atmosfernogo vozduha na zabolevaemost' naseleniya boleznyami organov dyhaniya $\mathrm{v}$ sisteme social'no-gigienicheskogo monitoringa. Vitebsk: VGU imeni P. M. Masherova, 40.

[3] Gvozdenko, T. A., Simonova, I. N., Antonyuk, M. V., Veremchuk, L. V., Vitkina, T. I. (2016). Pathogenetic markers of ecologically related respiratory diseases. Bulletin Physiology and Pathology of Respiration, 1 (62), 8-15. doi: http://doi.org/10.12737/23112

[4] Veremchuk, L. V., Kiku, P. F., Simonova, I. N. (2012). Vliyanie ekologo-gigienicheskih harakteristik vneshney sredy na immunno-metabolicheskie pokazateli krovi naseleniya s zabolevaniyami organov dyhaniya. Sibirskiy medicinskiy zhurnal, 111 (4), 126-130. 
[5] Veremchuk, L. V., Yankova, V. I., Vitkina, T. I., Barskova, L. S., Golohvast, K. S. (2015). Formirovanie zagryazneniya atmosfernogo vozduha goroda Vladivostoka i ego vliyanie na rasprostranenie bolezney organov dyhaniya. Sibirskiy nauchnyy medicinskiy zhurnal, 35 (4), 55-61.

[6] Soodaeva, S. K. (2012). Free radical mechanisms of injury in respiratory disease. Russian Pulmonology, 1, 5-10. doi: http://doi.org/10.18093/0869-0189-2012-0-1-5-10

[7] Chan, C. K., Yao, X. (2008). Air pollution in mega cities in China. Atmospheric Environment, 42 (1), 1-42. doi: http://doi.org/10.1016/j.atmosenv.2007.09.003

[8] Jiao, K., Xu, M., Liu, M. (2018). Health status and air pollution related socioeconomic concerns in urban China. International Journal for Equity in Health, 17 (1). doi: http://doi.org/10.1186/s12939018-0719-y

[9] Cong, X. (2018). Air pollution from industrial waste gas emissions is associated with cancer incidences in Shanghai, China. Environmental Science and Pollution Research, 25 (13), 13067-13078. doi: http://doi.org/10.1007/s11356-018-1538-9

[10] Dzherieva, I. S., Volkova, N. I. (2011). Oksidativnyy stress i vozmozhnost' ego korrekcii melatoninom. Klinicheskaya medicina, 89 (5), 21-25.

[11] Scherbakova, M. A. (2007). Antropogennoe zagryaznenie atmosfernogo vozduha v rayonah promyshlennogo centra, otlichayuschihsya po stepeni ekologicheskoy nagruzki (na primere g. Vitebska). Epizootologiya, immunobiologiya, farmakologiya i sanitariya, 1, 67-72.

[12] Scherbakova, M. A. (2017). Vliyanie antropogennyh faktorov okruzhayuschey sredy na respiratornuyu sistemu vzroslogo naseleniya. Vesnik VDU, 1 (94), 54-60

[13] Scherbakova, M. A. (2007). Harakteristika zagryazneniya atmosfernogo vozduha himicheskimi primesyami i vzaimosvyaz' kachestva vozdushnogo basseyna v razlichnyh ekologicheskih zonah goroda Vitebska. Epizootologiya, immunobiologiya, farmakologiya i sanitariya, 2, 74-79.

[14] Vasil'ev, P. V., Derbenev, D. P., Zhmakin, I. A., Alekseeva, Yu. A. (2012). Formirovanie fizicheskogo zdorov'ya podrostkov, prozhivayuschih v razlichnyh sanitarno-gigienicheskih usloviyah. Sanitarnyy vrach, 3, 18-25.

[15] Kotysheva, E. N., Dzyundzya, N. A., Bolotskaya, M. Yu. (2008). Analiz antropometricheskih pokazateley fizicheskogo razvitiya detey 5-7 let v usloviyah promyshlennogo goroda. Pediatriya, 87 (2), $140-143$.

[16] Polyanskaya, M. A. (2008). Spirometriya v ocenke narusheniy funkcii dyhatel'noy sistemy. Zdorovya Ukrainy, 3/1, 48-49.

[17] Preobrazhenskiy, V. S. (Ed.) (1975). Teoreticheskie osnovy rekreacionnoy geografii. Moscow: Nauka, 223.

[18] Simonova, I. N., Antonyuk, M. V. (2015). Rol' tehnogennogo zagryazneniya vozdushnoy sredy $\mathrm{v}$ razvitii bronho-legochnoy patologii. Zdorovie. Medicinskaya ekologiya. Nauka, 59 (1), 14-20.

[19] Sehic-Music, N., Goletic, S., Pihura, D., Music, L., Hasanovic, K. (2013). Effects of foundry industry on the environment. Metalurgija, 52 (4), 533-536.

[20] Sholkova, M. V., Docenko, E. A. (2016). Ocenka funkcii endoteliya u pacientov s hronicheskoy obstruktivnoy bolezn'yu legkih. Evraziyskiy kardiologicheskiy zhurnal, 3, 130. 